\title{
UJI TOKSISITAS SUBKRONIS EKSTRAK CURCUMA BEBAS MINYAK ATSIRI (ECBA) DITINJAU DARI PARAMETER PROFIL LEUKOSIT PADA TIKUS PUTIH GALUR WISTAR
}

\section{SUBCHRONIC TOXICITY STUDY OF VOLATILE OIL CURCUMA EXTRACT (ECBA) ON LEUKOCYTES PROFILE OF WISTAR RATS}

\author{
Verda Farida ${ }^{1}$, Zullies Ikawati ${ }^{2}$, Suwidjiyo Pramono ${ }^{2}$ \\ ${ }^{1}$ Fakultas Farmasi Universitas Ahmad Dahlan \\ Jl. Prof. Dr. Soepomo SH, Yogyakarta, Telp. (0274) 379418 \\ ${ }^{2}$ Fakultas Farmasi Universitas Gadjah Mada \\ Sekip Utara Yogyakarta 55281 Telp: (0274) 542907 \\ Email:verda@pharm.uad.ac.id
}

\begin{abstract}
ABSTRAK
Pengaruh Ekstrak Curcuma Bebas Minyak Atsiri (ECBA) dalam menurunkan kadar kolesterol dalam darah telah diteliti. ECBA sebagai obat antihiperlipidemia akan digunakan sebagai terapi jangka panjang. Penelitian ini dilakukan untuk mengetahui toksisitas subkronis ECBA terhadap gambaran leukosit tikus Wistar. Uji dilakukan terhadap 4 kelompok uji yang masing-masing terdiri dari 10 ekor tikus. Kelompok uji terdiri dari 3 kelompok yang diberi perlakuan ECBA dengan dosis 15 mg, 120 mg, dan 960 mg/200gBB; sedangkan kelompok kontrol diberi CMC-Na 0,5\%. Darah diambil pada hari ke-0, 45, dan 90 untuk dilihat gambaran leukosit. Hewan uji tetap dipelihara di bawah kondisi percobaan tanpa pemberian ECBA sampai hari ke-105 untuk uji reversibilitas. Dari hasil penelitian diperoleh bahwa pemberian ECBA selama 90 hari tidak mempengaruhi gambaran leukosit tikus Wistar.
\end{abstract}

Kata kunci: Ekstrak Curcuma Bebas Minyak Atsiri, kurkumin, toksisitas, leukosit.

\begin{abstract}
The effect of Volatil Oil of Curcuma Extraxt or Curcumin extract with minimum concentration of essential oil in reducing the levels of cholesterol in the blood has been examined. ECBA as antihyperlipidemic agent is given for a long - term therapeutic purpose. This experiment was performed to investigate the subchronic toxicity of ECBA on leukocytes profile of Wistar rats. ECBA was investigated at dose $15 \mathrm{mg}, 120 \mathrm{mg}$, and $960 \mathrm{mg} / 200 \mathrm{~g}$ body weight for 90 days in 40 male Wistar rats. CMC-Na was used for control. The blood was examined for the leukocytes profile on day 0,45 , and 90 . The rats were still maintained under experimental conditions without giving ECBA until day 105 for the reversibility test. The result showed that the administration of ECBA for 90 days did not affect leukocytes profile of Wistar rats.
\end{abstract}

Keywords: Ekstrak Curcuma Bebas Minyak Atsiri, curcumin, toxicity, leukocytes. 


\section{PENDAHULUAN}

Temulawak (Curcuma xanthorrhiza Roxb.) merupakan tanaman asli Indonesia dan termasuk salah satu jenis temu-temuan yang paling banyak digunakan sebagai bahan baku obat tradisional (Dalimartha, 2000). Rimpang temulawak mengandung kurkuminoid, minyak atsiri, pati, protein, lemak, selulosa, dan mineral. Kurkuminoid pada temulawak terdiri dari kurkumin dan desmetoksi kurkumin. Kurkumin dengan nama IUPAC (International Union of Pure and Applied Chemistry) 1,7-bis (4-hydroxy3-methoxyphenyl) hepta-1,6-diene-3,5-dione (Gambar 1), adalah komponen utama yang terkandung dalam Curcuma, biasanya digunakan sebagai pemberi warna kuning dan pemberi rasa pada makanan. Kurkumin menunjukkan aktivitas antikarsinogenik pada binatang dan memiliki aktivitas sebagai antioksidan (Lin dan Lin-Shiau, 2001; Park dkk., 2010).

Shin dkk (2011) menemukan bahwa penggunaan kurkumin dalam jangka panjang dapat menurunkan kolesterol plasma dan kolesterol hepatik. Pada penelitian yang sama, diketahui juga bahwa kurkumin dapat menekan lesi aterosklerotik awal dengan mengubah ekspresi gen pembentuk lemak dan kolesterol. Namun, temulawak ternyata memiliki efek dapat merangsang produksi cairan empedu di hati sehingga proses pencernaan dan absorpsi lemak di usus terjadi lebih cepat, atau disebut dengan choleretic. Proses ini akan mempercepat proses pengosongan lambung yang pada akhirnya dapat meningkatkan nafsu makan. Kandungan dalam temulawak yang bertanggung jawab dalam merangsang nafsu makan adalah minyak atsiri berupa d-camphor (Ozaki dan Liang, 1988; Awalin, 1996). Tidak adanya kontrol terhadap jenis makanan yang dikonsumsi akibat nafsu makan bertambah dapat mengakibatkan peningkatan jumlah kolesterol. Oleh karena itu, agar temulawak dapat berefek secara optimal sebagai antidislipidemia maka minyak atsiri tersebut harus dihilangkan.

Minyak atsiri dapat dihilangkan dengan cara ekstraksi terpurifikasi (Barliani, 2005). Ekstrak temulawak dimana kandungan minyak atsirinya minimal disebut sebagai Ekstrak Curcuma Bebas Minyak Atsiri (ECBA). Hasil penelitian Riyadi (2005) menunjukkan bahwa pemberian ekstrak curcuma bebas minyak atsiri (ECBA) selama 45 hari mempunyai efek menurunkan kadar kolesterol LDL serum dan menaikkan kadar kolesterol HDL serum dengan dosis optimal sebesar $15 \mathrm{mg} / 200 \mathrm{~g}$ BB tikus yang setara dengan dosis 600-850 mg sehari pada manusia.<smiles>COc1cc(/C=C/C(=O)CC(=O)/C=C/c2ccc(O)c(OC)c2)ccc1O</smiles>

Gambar 1. Struktur Kurkumin [1,7-bis(4hydroxy-3-methoxyphenyl)hepta-1,6diene-3,5-dione] diadaptasi dari Olszanecki (2005)

Pada umumnya antidislipidemia pada kasus berat atau kasus yang bersifat herediter dianjurkan digunakan dalam jangka panjang (Kamaluddin, 1993). Berdasarkan uraian tersebut maka perlu dilakukan suatu uji toksisitas untuk mengetahui efek berbahaya yang mungkin terjadi dalam penggunaan jangka panjang. Salah satu uji yang dapat digunakan adalah uji toksisitas subkronis, yaitu uji yang dilakukan dengan memberikan suatu obat secara berulang-ulang (Lu, 2009). Uji toksisitas subkronis dapat memberikan informasi kepada masyarakat tentang potensi ketoksikan ECBA sebagai obat antidislipidemia. Salah satu parameter yang dapat diambil sebagai gambaran terjadinya toksisitas adalah profil leukosit (Lu, 2009).

\section{METODE PENELITIAN}

\section{Alat}

Alat-alat yang digunakan dalam penelitian ini adalah timbangan hewan, kandang tikus biasa yang dilengkapi dengan tempat pakan dan botol minum, kandang metabolit, serta spuit injeksi per oral. Untuk membuat sediaan uji digunakan neraca analitik elektrik, peralatan gelas yang lazim digunakan, kompor listrik, dan pengaduk magnetik (magnetic stirrer).

\section{Bahan}

Bahan utama yang digunakan dalam penelitian ini adalah Ekstrak Curcuma Bebas 
Minyak Atsiri (ECBA) yang diekstraksi dan dimurnikan oleh Prof. Dr. Suwidjiyo Pramono, DEA., Apt. dari Fakultas Farmasi Universitas Gadjah Mada Yogyakarta.

Hewan uji yang digunakan adalah tikus (Rattus norvegicus) putih galur Wistar, jantan, sehat, umur $\pm 1,5$ bulan, bobot \pm 150 gram, diperoleh dari Laboratorium Farmakologi dan Toksikologi Fakultas Farmasi Universitas Gadjah Mada Yogyakarta. Tikus dipelihara dalam kandang yang dilengkapi tempat makan dan minum secara terpisah antar individu.

\section{Jalannya Penelitian}

\section{Pengelompokan hewan uji}

Empat puluh ekor tikus jantan dibagi menjadi 4 kelompok masing-masing 10 ekor tikus, yaitu:
a. Kelompok I
CMC-Na 0,5\% 5 ml/ 200 g BB
b. Kelompok II
ECBA dosis $15 \mathrm{mg} / 200 \mathrm{~g}$ BB
c. Kelompok III
ECBA dosis $120 \mathrm{mg} / 200 \mathrm{~g}$ BB
d. Kelompok IV
ECBA dosis $960 \mathrm{mg} / 200 \mathrm{~g}$ BB

\section{Pembuatan sediaan uji}

Sediaan uji dibuat dengan menyuspensikan ECBA dengan berbagai dosis ke dalam larutan CMC-Na 0,5\%. Larutan CMC-Na dibuat dengan melarutkan 0,5 bagian serbuk CMC-Na ke dalam 100 bagian air suling hangat.

\section{Penetapan dosis}

Dosis rendah ditetapkan berdasarkan dosis terapi hasil penelitian efek farmakologi ECBA terhadap kadar kolesterol HDL dan LDL pada tikus jantan galur wistar yaitu sebesar $15 \mathrm{mg} / 200$ g BB tikus. Dosis tengah dan dosis tinggi ditetapkan dengan menggunakan faktor kelipatan 8 yaitu 120 mg/200 g BB tikus dan 960 mg/200 g BB tikus.

\section{Perlakuan hewan uji}

Hewan uji diadaptasikan dengan kondisi laboratorium selama satu minggu sebelum penelitian dimulai. Tikus dimasukkan ke dalam kandang. ECBA diberikan setiap hari selama 90 hari. Uji reversibilitas dilakukan selama 15 hari tanpa pemberian ECBA.

\section{Pemeriksaan leukosit}

Pemeriksaan leukosit dilakukan pada hari ke-0, 45, dan 90 serta pada akhir uji reversibilitas (hari ke-105). Pencuplikan darah dilakukan di Laboratorium Patologi Klinik Fakultas Kedokteran Hewan Universitas Gadjah Mada. Darah diambil melalui vena mata (orbitalis) dengan menggunakan tabung hematokrit. Darah ditampung dalam eppendorf $\AA$ tube dengan antikoagulan etilen diamin tetra asetat (EDTA) untuk mendapatkan plasma.

Penghitungan jumlah leukosit dilakukan dengan menggunakan pipet Thoma leukosit. Sampel darah yang telah diberi EDTA dihisap pada pipet Thoma sampai batas "0,5". Pipet kemudian dimasukkan dalam larutan pengencer untuk leukosit (larutan Turk) dan dihisap sampai batas angka "11". Pipet dibolak-balikan kira-kira 3 menit dengan menggerakkan $1 / 4$ lingkaran, lalu 2-3 tetes dibuang. Darah diteteskan di pinggir kamar hitung dan diperiksa di bawah mikroskop. Penghitungan leukosit dilakukan pada empat kotak besar dari kamar hitung. Jumlah leukosit per $\mathrm{mm}^{3}$ adalah jumlah sel terhitung dikalikan lima puluh (Benjamin, 1979).

\section{Analisis}

Data penimbangan berat badan, asupan makan, asupan minum, dan pemeriksaan hematologi dianalisis secara statistik menggunakan one way ANOVA.

\section{HASIL DAN PEMBAHASAN}

Penelitian ini bertujuan untuk mengetahui toksisitas subkronis Ekstrak Curcuma Bebas Minyak Atsiri (ECBA) yang diberikan secara per oral pada pemakaian jangka panjang dengan berbagai tingkat dosis terhadap gambaran leukosit hewan uji. Dalam penelitian ini digunakan hewan uji yaitu 40 ekor tikus jantan galur Wistar. Tolok ukur dalam uji ketoksikan sub kronis dalam penelitian ini adalah gambaran leukosit sebagai salah satu parameter toksisitas.

Hasil penghitungan jumlah leukosit dapat dilihat pada TabelI. Hasil ANOVA pada hari ke-0 
tidak menunjukkan adanya perbedaan jumlah leukosit yang signifikan $(p<0,05)$ antara kelompok tikus kontrol (I) dengan semua kelompok perlakuan ECBA, sehingga dapat dikatakan semua tikus uji memiliki kondisi yang sama.

Tabel I. Gambaran jumlah leukosit tikus jantan yang diberi perlakuan ECBA selama 90 hari dan reversibi litasnya selama 15 hari

\begin{tabular}{|c|c|c|c|c|}
\hline \multirow[b]{2}{*}{ Kelompok } & \multicolumn{4}{|c|}{ Jumlah rata-rata leukosit \pm SD $\left(\right.$ ribu/mm³ $\mathbf{m}^{3}$} \\
\hline & $\begin{array}{c}\text { Hari ke-0 } \\
(n=10)\end{array}$ & $\begin{array}{c}\text { Hari ke-45 } \\
(n=10)\end{array}$ & $\begin{array}{l}\text { Hari ke-90 } \\
(n=10)\end{array}$ & $\begin{array}{c}\text { Hari ke-105 } \\
(n=5)\end{array}$ \\
\hline Kontrol (I) & $5,75 \pm 1,87$ & $3,23 \pm 0,81$ & $6,09 \pm 1,87$ & $10,56 \pm 4,55$ \\
\hline 15 mg/200 g (II) & $6,55 \pm 1,96$ & $2,97 \pm 1,09$ & $4,77 \pm 1,27$ & $6,91 \pm 1,76$ \\
\hline 120 mg/200 g (III) & $4,08 \pm 0,93$ & $5,44 \pm 1,46^{*}$ & $5,46 \pm 1,06$ & $5,20 \pm 2,40^{*}$ \\
\hline $960 \mathrm{mg} / 200 \mathrm{~g}(\mathrm{IV})$ & $6,96 \pm 2,65$ & $5,48 \pm 1,56^{*}$ & $5,82 \pm 1,38$ & $5,32 \pm 1,56 *$ \\
\hline Normal $^{\mathrm{a}}$ & \multicolumn{2}{|c|}{$1,96-8,25$} & \multicolumn{2}{|c|}{$1,98-11,06$} \\
\hline
\end{tabular}

Pada hari ke-45 terdapat perbedaan jumlah leukosit antara kelompok kontrol (I) dengan kelompok dosis 120 mg/ 200 g BB (III) dan 960 mg/ 200 g BB (IV). Namun pada hari ke-90 tidak tampak adanya perbedaan jumlah leukosit yang signifikan antara kelompok kontrol dengan semua kelompok perlakuan ECBA, sehingga dapat disimpulkan bahwa perbedaan signifikan jumlah leukosit yang terjadi pada hari ke-45 bukan disebabkan oleh ECBA.

Dari Gambar 2 terlihat bahwa jumlah leukosit kontrol mengalami kenaikan yang signifikan saat pemberian ECBA dihentikan selama 15 hari, sedangkan pada kelompok perlakuan ECBA jumlah leukosit tidak berbeda signifikan dengan jumlah leukosit saat pemberian belum dilakukan. Peningkatan leukosit kelompok kontrol ini melebihi batas normal yang dapat terjadi akibat stres fisiologi maupun infeksi yang bukan karena disebabkan ECBA karena perubahan leukosit terjadi (Latimer dkk, 2003; Davis dkk, 2008).

Penelitian ini memiliki keterbatasan antara lain tidak terjaminnya kesehatan patologis hewan uji yang digunakan. Hal ini mempengaruhi hasil pemeriksaan leukosit yang dilakukan.

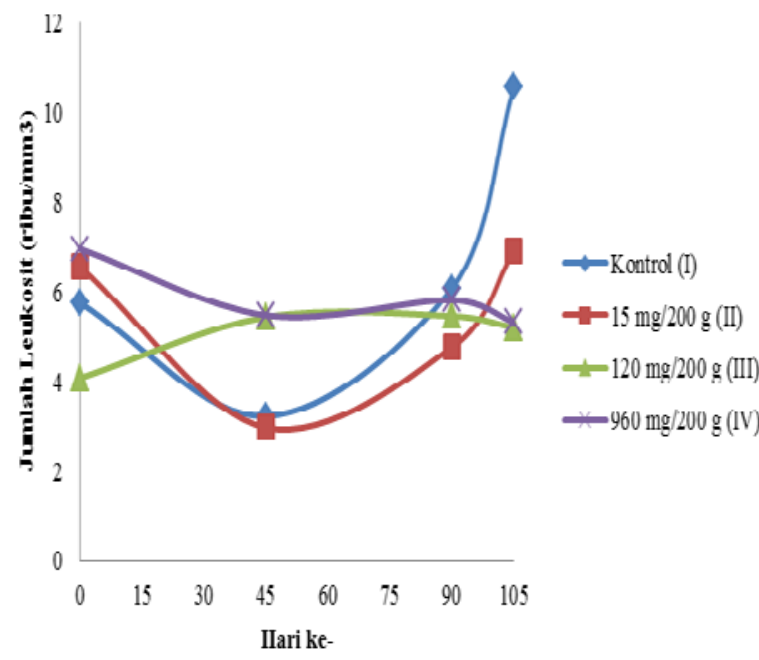

Gambar 2. Grafik rata-rata jumlah leukosit (ribu/ $\mathrm{mm}^{3}$ ) tikus jantan yang diberi perlakuan ECBA selama 90 hari dan reversibilitas selama 15 hari

\section{KESIMPULAN}

Dari hasil penelitian dapat diambil kesimpulan bahwa pemberian ECBA selama 90 hari tidak memberikan efek toksis terhadap gambaranleukosit. 


\section{DAFTAR PUSTAKA}

Awalin, N. 1996. Minyak Atsiri Rimpang Temulawak, Pengaruhnya terhadap Kenaikan Berat Badan Tikus Putih Jantan dan Analisis Kandungan Kimianya, Skripsi, Fakultas Farmasi Universitas Gadjah Mada Yogyakarta.

Barliani, N. 2005. Pembuatan Ekstrak Temulawak (Curcuma Xanthorriza Roxb.) Terpurifikasi dan Standar disasinya Berdasarkan Kandungan Kurkumin, Skripsi, Fakultas Farmasi Universitas Gadjah Mada Yogyakarta.

Benjamin, M. M. 1979. Outline Veterinary Hematology, 4th ed, The Iowa State University Press, Iowa.

Dalimartha, S. 2000. Atlas Tumbuhan Obat Indonesia-Jilid 2, Trubus Agriwidya, Jakarta.

Davis, A. K., Maney, D. L., dan Maerz, J. C. 2008. The use of leukocyte profiles to measure stress in vertebrates: a review for ecologists, Functional Ecology, 22, 760 772.

Kamaluddin, M. T. 1993. Farmakologi Obat Anti Hiperlipidemia, Cermin Dunia Kedokteran, 85, 26-32.

Latimer, K. S., Mahaffey, E. A., dan Prasse, K. W. 2003. Duncan \& Prasse's Veterinary Laboratory Medicine: Clinical Pathology, 4th ed., Iowa State Press, Blackwell Publishing Company, Ames, Iowa.

Lin, J.K. dan Lin-Shiau, S.Y. 2001. Mechanisms of Cancer Chemoprevention by Curcumin,
Proc Natl Sci Counc Repub China B., 25(2), 59-66.

Lu, F. C., dan Kacew, S. K. 2009. Lu’s Basic Toxicology: Fundamentals, Target Organs, and Risk Assessment, 5th ed., Informa Healthcare USA, Inc., New York.

Olszanecki, R., Jawien, J., Gajda, M., Mateuszuk, L., Gebska, A., Korabiowska, M., Chlopicki, S., dan Korbut, R. 2005. Effect of Curcumin on Atherosclerosis in ApoE/LDLR-Double Knockout Mice, Journal of Physiology and Pharmacology, 56(4), 627-635.

Ozaki, Y. dan Liang, O. B. 1988. Cholagogic action of the essential oil obtained from Curcuma xanthorrhiza Roxb., Shoyakugaku Zasshi , 42(4): 257-263.

Park, J. dan Conteas, C. N. 2010. Anticarcinogenic properties of curcumin on colorectal cancer, World J Gastrointest Oncol., 2(4): 169-176.

Riyadi, S. H. 2006. Pengaruh Pemberian Ekstrak Temulawak (Curcuma xanthorrhiza Roxb.) Terpurifikasi Terhadap Kadar Kolesterol HDL dan LDL Tikus Jantan Wistar dengan Diet Lemak Tinggi, Skripsi, Fakultas Farmasi Universitas Gadjah Mada Yogyakarta.

Shin, S. K., Ha, T. Y., McGregor, R. A., dan Choi, M. S. 2011. Long-term curcumin administration protects against atherosclerosis via hepatic regulation of lipoprotein cholesterol metabolism, $\mathrm{Mol}$ Nutr Food Res, 55(12): 1829 - 40. 